DOI: $10.17951 / 1 r p .2019 .38 .2 \cdot 169-180$

\title{
Kazimierz Pierzcha乇A
}

Katolicki Uniwersytet Lubelski Jana Pawła II

ORCID: 0000-0001-9972-943X

\section{AKSJOLOGICZNE KONTEKSTY WYCHOWANIA RESOCJALIZACYJNEGO}

\begin{abstract}
Streszczenie: Zadaniem artykułu jest przedstawienie zasadniczych zagadnień aksjologicznych kontekstów wychowania resocjalizacyjnego. Zastosowaną metodą jest opracowanie materiałów oraz edycja krytyczna. Przedmiotem niniejszej publikacji jest próba analizy ogólnie pojętych zagadnień aksjologicznych w kontekście procesu wychowania resocjalizacyjnego, zagadnień zdaniem autora wiodących, wymagających wyjaśnienia, aby czytelnik mógł odnaleźć propozycje ich rozwiązania lub też samodzielnie mógł odkrywać nowe możliwości i konstruować własne kategorie opisu i analizy złożonych współczesnych kwestii wychowawczych oraz stawiać własne pytania i twórczo poszukiwać dróg odpowiedzi, przy okazji przekraczając ograniczenia i bariery.
\end{abstract}

Słowa kluczowe: aksjologia, niedostosowanie społeczne, resocjalizacja, przestępca, wychowanek, wychowanie resocjalizacyjne

\section{DEFINICJA AUTORSKA}

„Resocjalizacja to nauka i praktyka społeczna, określająca zakres działań wychowawczych, opiekuńczych i terapeutycznych. Jest to proces zmierzający do wykształcenia u osób niedostosowanych społecznie zmian w obszarze samoświadomości, samowychowania, samopotwierdzenia i samorefleksyjności” (Pierzchała 2017, s. 95).

\section{WSTĘP}

Terminu „aksjologia” użył jako pierwszy Paul Lapie w Logique de la volonté (1902 r.), a utrwalił go Eduard von Hartmann w Grundriss der Axiologie (1908 r.); współcześnie wiąże się z problematyką aksjologiczną, także teologią (naukową refleksją 
o celach), a w ujęciu filozoficznym wyróżnia się w aksjologii dwa szczególne działy: etykę i estetykę, w klasycznej filozofii traktowane odrębnie i autonomicznie. Aksjologia zajmuje się naturą wartości, jej kryteriami, rodzajami, hierarchią, sposobami poznawania (wartościowania) i przyswajania, funkcjami wartości w życiu człowieka, kultury, społeczeństwa, gospodarki, ekonomii (Maj 2016, s. 82-91). W wąskim znaczeniu przedmiotem aksjologii jest szczegółowa teoria wartości, która wchodzi w skład poszczególnych dyscyplin naukowych (np. filozofii, psychologii, socjologii, pedagogiki, ekonomii) oraz stanowi dziedzinę rozważań nad określonymi rodzajami (kategoriami) wartości (Ostrowska 2006, s. 393). Przedmiotem badań aksjologii pedagogicznej są wartości i procesy wartościowania oraz ich teorie mające zastosowanie w pedagogice. Jako dziedzina wiedzy wyłania się „ze skrzyżowania dwóch dyscyplin - pedagogiki ogólnej i aksjologii, tworząc wspólną przestrzeń wiedzy" (Ostrowska 2006, s. 404). W węższym rozumieniu określana jest jako dział pedagogiki ogólnej zajmujący się „tymi wartościami, które wychowanie ma zaszczepić w wychowanku” (Okoń 1998). „Istnieje silny wzajemny związek odczucia sensu jako czynnika motywującego ze światem wartości w ogóle i sfery sumienia $\mathrm{z}$ wartościami moralnymi w szczególności. W rezultacie można mówić o profilu aksjologicznej świadomości człowieka jako określającej jego osobową jakość" (Pierzchała 2016, s. 103). Jest faktem, że problematyka aksjologiczna sięga do rzeczywistości ludzkiej egzystencji, ponieważ „nasz świat jest światem wartości" (Tischner 2011, s. 483), rzeczy i spraw ważnych, cennych, pozytywnych i negatywnych (Maj 2016, s. 83).

Przedmiotem niniejszej publikacji jest próba analizy ogólnie pojętych zagadnień aksjologicznych w kontekście procesu resocjalizacji, zagadnień zdaniem autora wiodących, wymagających wyjaśnienia, aby czytelnik mógł odnaleźć propozycje ich rozwiązania lub też samodzielnie mógł odkrywać nowe możliwości i konstruować własne kategorie opisu i analizy złożonych, współczesnych kwestii wychowawczych oraz stawiać własne pytania i twórczo poszukiwać dróg odpowiedzi, przy okazji przekraczając ograniczenia i bariery. Działania poprawcze, które powinny służyć przemianie jednostki, oraz czynniki towarzyszące ukształtowaniu człowieka, w miarę rozwoju nauki i świadomego oddziaływania (np. penitencjarnego) przez lata twórczo rozwinęły się. Doprowadziło to do rozwoju dziedziny zajmującej się problemami człowieka nieprzystosowanego społecznie - resocjalizacji. Współcześnie nauka piórem wielu naukowców i praktyków wypracowała konkretne filary oddziaływań korekcyjnych. Powszechnie zalicza się do nich: zajęcia kulturalno-oświatowe, zajęcia sportowe, pracę, naukę, czy też pomoc postpenitencjarną.

Metodologią zastosowaną przy pisaniu przedmiotowej publikacji stało się przeprowadzenie krytycznej analizy literatury, własnego dorobku naukowego, przepisów prawa i innych dokumentów, w tym dostępnych zasobów internetowych. 


\section{RESOCJALIZACJA A WYCHOWANIE RESOCJALIZUJACE}

Resocjalizacja zawiera w sobie wychowanie resocjalizujące: jest to typowa część metodyczna pracy z podopiecznym, a skoro to metodyka - musi mieć określony cel, a cel ten musi być optymalny, np. zmiana osobowości wychowanka.

Wychowanie resocjalizujące jest to wychowanie, które stosuje się wobec osób, które wykazują zaburzenia socjalizacji, a ich przejawem są zachowania aspołeczne lub antyspołeczne. Wobec dzieci i młodzieży to działania wymagające specjalnych oddziaływań na procesy psychiczne w taki sposób, by wywołać zmiany czynności jednostki. Zmiany te mają polegać na eliminowaniu reakcji negatywnych na określone naciski społeczne, np. zlecenia zadaniowe, naciski w postaci norm (Czapów 1978).

\section{AKSJOLOGIA WSPÓŁCZESNEJ RESOCJALIZACJI}

„Ale jaki jest punkt wyjścia aksjologii resocjalizacji? Trzeba by zacząć od całej tradycji rozumienia człowieka jako osoby w jego rzeczywistej, niezredukowanej postaci i dynamice, $w$ wielowymiarowej osobowej pełni, a zarazem indywidualnej, niepowtarzalnej autonomii. Dostrzegając taką wartość człowieka, uwzględniamy przynależne mu poczucie osobowej godności i dostrzegamy jego związek ze sferą wartości i odpowiednią ich hierarchią. Jest to oczywiście obraz człowieka wzorcowy, lecz jednocześnie prawdziwy, gdyż immanentny jego naturze" (Pierzchała 2016, s. 111).

Osoba podlegająca resocjalizacji musi przejść o wiele dłuższą drogę niż ktoś, kto jest dobrze zaadaptowany w społeczeństwie, aby zbliżyć się do harmonijnie funkcjonującego obrazu siebie, aby stać się pełnoprawnym członkiem społeczności.

Odpowiednie relacje człowieka ze środowiskiem, ze społeczeństwem, należą do najistotniejszych celów resocjalizacji, są uwarunkowane wieloma czynnikami i procesami. Zasadniczym „,...] celem pomocy udzielanej osobie pozbawionej wolności jest uprzytomnienie jej popełnionych błędów, ich naprawa oraz wejście na drogę godnego życia w społeczeństwie" (Pierzchała 2013, s. 12). Ustalenie aksjologicznych punktów odniesienia określanych w procesie resocjalizacji przyzwala na teoretyczne posegregowanie zabiegów wychowawczych, przy czym należy pamiętać, że współzależności te zmieniają się często wraz z panującymi tendencjami społeczno-politycznymi. Zabiegi wychowawcze, współcześnie nazywane resocjalizacją (w krajach anglojęzycznych - rehabilitacją społeczną - social rehabilitation), z punktu widzenia aksjologicznego to dążenie w kierunku dobra społecznego, które zostaje zaburzone obyczajowo lub przestępczo, poprzez niedostosowaną 
społecznie jednostkę. Realizacja szeroko zakrojonych działań resocjalizacyjnych w paradygmacie (przyjętym sposobie widzenia rzeczywistości) funkcjonalno-strukturalnym, ukierunkowanym głównie na dążeniu do pozyskania wartości dobra społecznego spowodowała wyznaczenie dla resocjalizacji zasadniczego zadania $w$ postaci przemiany osobowości wychowanka w kierunku społecznie pożądanym. Korygowanie (modyfikowanie, przekształcanie, formowanie, kształcenie, doskonalenie, prostowanie - Pytka 2005) osobowości, niezależnie od zmian społeczno-kulturowych, wciąż pozostaje istotną wartością dla samej resocjalizacji. Jednakże w myśl współczesnych trendów panujących w naukach społecznych, istotą posunięć wychowawczych staje się nie tyle zmiana osobowości wychowanka, ale wywołanie swoistej synergii pomiędzy resocjalizowaną jednostką a środowiskiem, tak aby i wychowanek, i jego środowisko mogli czerpać zbieżne korzyści ze wzajemnych stosunków (Jaworska 2012, s. 25-29).

Przywołując słowa nestora polskiej resocjalizacji Czesława Czapówa, to paradoksalnie (biorąc pod uwagę fakt, że znaczna część zabiegów resocjalizacyjnych odbywa się placówkach zamkniętych) podstawową wartością resocjalizacji jest... wolność jednostki (Czapów 1978). Wolność to jedno z podstawowych pojęć politycznych, mające również odniesienia filozoficzne, religijne i ekonomiczne. Stanowi ona w życiu każdego człowieka wartość finalną, autoteliczną (będącą celem samym w sobie), a równocześnie jest ona środkiem realizacji innych wartości i dóbr w realizacji codziennych potrzeb jednostki. Człowiek jako stworzenie relatywnie autonomiczne (prawo do samostanowienia), posiada określony zakres swobody myślenia i działania (prawa konstytucyjne), w konsekwencji posiada określony zakres pozytywnej oraz negatywnej wolności. Osoba pozbawiona tych możliwości (wartości) zaczyna tracić swoją podmiotowość, a nadzór nad nią przejmują różnorakie okoliczności. W skrajnym przypadku negatywnym rezultatem - uprzedmiotowienia, utraty swobód wolnościowych i podmiotowych - staje się patologia zachowań jednostki. Przy deficycie wolności społeczność zazwyczaj podejmuje próby wyzwalania się. Zjawisko podążania do wolności osobistej zauważalne jest już $\mathrm{w}$ szkole, $\mathrm{w}$ formie oporu ucznia manifestującego zachowania nazywane popularnie „niedostosowaniem społecznym”. Wszystko to, co nie wynika $\mathrm{z}$ indywidualnych potrzeb jednostki, często uważane jest za blokujące jego tendencję samorealizacyjną (Szkudlarek, Śliwerski 2010). Anetta Jaworska jest zdania, że „Położenie nacisku na wolność jednostki jest jednocześnie przeciwstawieniem wizji nastawionej na transmisję kulturową - wizji indywidualności, przeciwstawieniem niepowtarzalności, jednostkowości i twórczości każdego człowieka - stereotypom i nadanym z góry wartościom. Instytucje resocjalizacyjne (głównie zakłady karne), spełniając swoje funkcje utylitarne, drastycznie ograniczają jednak swobodę wyborów, jakie mogą podejmować wychowankowie. Brak 
możliwości decydowania to jednocześnie utrata szansy na kształtowanie i rozwój osobowości. Jako narzędzie kontroli instytucje resocjalizacyjne selekcjonują i separują jednostkę od społeczeństwa. Osoby, których życie jest pełne gróźb i lęku przed karą, nie mają sposobności, by się uczyć, czym jest odpowiedzialność za siebie" (Jaworska 2012, s. 26-27). Należy pamiętać, że myśląc o poczuciu własnej wartości bez odpowiedzialności za siebie, wypacza się jej obraz, a próbując ją bez tego zdobyć - oczekuje się niemożliwego. Poczucie własnej wartości nie powinno być zbyt duże, jednakże poczucie odpowiedzialności za siebie - już tak.

\section{ROZWÓJ WYCHOWANKA}

Żeby można było mówić o prawdziwym rozwoju wychowanka i jego prawidłowym funkcjonowaniu społecznym, imperatywami (nakazem lub normą) w resocjalizacji jest pielęgnowanie m.in. takich wartości jak wolność. Andrzej Bałandynowicz jest zdania, że „[...] wolność jest jedną z naczelnych kategorii aksjologicznych, do której zmierza każdy człowiek i która zakresem znaczeniowym obejmuje zarówno elementy przedmiotowe, jak i przeżywane stany psychiczne" (Bałandynowicz 2015, s. 16). Wolność działania i myślenia, niezależność osobista, wolność wyboru (w zakresie, na jaki pozwalają warunki, w których odbywa się resocjalizacja), to wyłączna szansa na zbudowanie $\mathrm{w}$ wychowanku zdecydowania na ponoszenie odpowiedzialności za swoje czyny i innych, a także otwarcie przed jednostką szerokiego pola autokreacji, poprzez kreowanie samego siebie, tworzenie własnego wizerunku itp.

\section{WSPÓŁCZESNA AKSJOLOGIA WYCHOWANIA RESOCJALIZACYJNEGO}

Współczesna aksjologia resocjalizacji wykorzystuje szereg uznanych wartości, w tym również takich, które pokazują nie tylko powiązanie jednostki ze światem społecznym i kultury, ale również umiejscowienie tejże jednostki w świecie przyrody, z którą utrzymuje nierozerwalną współzależność. Nadal jednak przeważającym paradygmatem teoretycznym (naukowym) - na którym osadza się wychowanie resocjalizacyjne jednostki niedostosowanej społecznie - utrzymuje się paradygmat strukturalno-funkcjonalny, w którym dobro społeczeństwa konfrontowane jest z dobrem resocjalizowanej jednostki (Konopczyński 2010). Tymczasem autentyczny sens etyki, będącej prawdziwym komponentem rzetelnego wychowania (w przeciwieństwie do tresury), wyraża się równowagą pomiędzy dobrem wspólnym a dobrem jednostki. Celem dobra wspólnego jest zapewnienie wolności jednostkom. 
Dobro wspólne nie może być wartością samą w sobie, tak samo jak nie powinna nią być wolność jednostki, gdyż ta realizować się może jedynie w grupie. Jednostki, $\mathrm{w}$ trosce o dobro wspólne, muszą wypracować swoisty konsensus, porozumienie, dzięki któremu cała grupa, ale również każdy z osobna będzie mógł się rozwijać. I tak wiodącymi założeniami wychowania winny być wolność i podmiotowość każdej jednostki, w tym również tej, która przez własne działania przestępcze niejednokrotnie podmiotowości tej przeczyła. Należy pamiętać, iż eksponowanie godności, wolności i podmiotowości człowieka w żadnym innym wychowaniu nie jest tak bardzo niezbędne jak w wychowaniu resocjalizacyjnym. Nowoczesna resocjalizacja zakłada, że przymus (tresura) w resocjalizacji powinien być używany w ostateczności, a prawdziwa resocjalizacja nie może zakładać poniżania drugiego człowieka, lecz winna ona wzbudzać jego poczucia godności, nie w oparciu o zniewolenie, a poprzez pokazanie innego życia, nie poprzez wzbudzanie lęku, lecz poprzez minimalizowanie sytuacji opresyjno-lękowej, łącznie z odrzuceniem kary pozbawienia wolności jako formy poprawy sprawców przestępstw. Andrzej Bałandynowicz twierdzi, że „[...] kiedy osoba będzie traktowana jako twórca samej siebie, będzie chciała się zmienić, to nie kara ma wymusić zmianę, to ona ma akceptować karę, w wyniku której będzie się musiała zmienić, a społeczeństwo będzie tylko kontrolowało tę zmianę" (Bałandynowicz 2011, s. 235). Są to bardzo ważne słowa mówiące o fundamentalnej i regulacyjnej roli, jaką mogą odgrywać w życiu człowieka uwewnętrzniony system wartości oraz rozwinięta świadomość aksjologiczna. Jest to zarazem wyraz dalekowzrocznej wiary w pozytywny wymiar ludzkiej wolności (Pierzchała 2016, s. 59-60).

\section{RESOCJALIZACJA WYCHOWANKA}

\section{Resocjalizacja to budowa w wychowanku tożsamości osobowej i społecznej,} wspartej antropologią optymistyczną (nauką o człowieku, jego pochodzeniu, rozwoju), wyrażającą się wiarą w dobro natury ludzkiej uśpionej na skutek wcześniejszych, często olbrzymich zaniedbań wychowawczych (Nowak, Magier, Szewczak 2010). Wydaje się, że z takiego punktu widzenia w ujęciu aksjologii resocjalizacji nie jest najważniejsze, „kim jest człowiek”, ale „kim może się stać” (Suchodolski 1967, s. 31), wyeksponowanie autokreatywnego (twórczego) wymiaru ludzkiej egzystencji, a także pokazanie zdolności człowieka (włącznie z tym, który wkroczył na drogę przestępstwa) do budowania samego siebie (Jaworska 2012, s. 25-29).

W resocjalizacji osoby niedostosowanej społecznie etyka oznacza w głównej mierze homeostazę (synergię) pomiędzy dobrem jednostki a dobrem społecznym. Wydźwięk wartości w resocjalizacji powinien być mierzony zdolnością do nadawania 
sensu oraz wzbudzania prawdziwej radości. Prawdziwą wartością w resocjalizacji jest możliwość odkrywania autentycznego sensu życia przez resocjalizowanych wychowanków, kształtowania celu oraz odnajdywania szczęścia, powstrzymywania ideologii hedonizmu (postawy życiowej wyrażającej się dążeniem do przyjemności jako rzeczy w życiu najważniejszej i unikaniem bądź minimalizowaniem spraw przykrych) i konsumpcji. Otwarcie się na świat wartości staje się dla człowieka ucieczką przed nihilizmem (odrzucaniem norm, zasad, wartości społecznych, religijnych, estetycznych, etycznych i innych) (Tischner 1982, s. 408-410), a bez takich wartości najczęściej człowieka otacza pustka, bezsens, często prowadząc do przestępczości i uzależnień (Jaworska 2012, s. 25-29). Niska skuteczność resocjalizacji wynika m.in. z bagatelizowania w praktyce i teorii pedagogiki resocjalizacyjnej różnych detali związanych z poszukiwaniem sensu życia.

Jak już wcześniej zaznaczyłem, aksjologia współczesnej resocjalizacji podkreśla również założenia antropologiczne, których sednem jest konieczność uznania siebie samego jako najwyższej wartości (Tischner 2010). Brak poczucia własnej wartości stanowi jeden z głównych czynników determinujących (determinantów) zachowania dewiacyjne i przestępcze. Resocjalizacja ukierunkowana na autentyczną zmianę człowieka powinna otwierać się na jak najwięcej aspektów związanych z ogólnie pojętą „kondycja ludzką”. Józef Tischner jest zdania, że ład aksjologiczny eksponuje szczególną wartość człowieka, „bowiem w człowieku wartość stała się osobą” (Tischner 1984). Równocześnie należy pamiętać, że: „[...] nie wolno zmieniać ludzi za wszelką cenę. Wychowanie zaczyna się od tego, że przed wszystkim [...] pozwala się drugiemu być” (Walczak 2007, s. 157). „Nie można również zbagatelizować faktu, że niektórzy przestępcy to ludzie o osobowości psychopatycznej, a już samo negatywne oddziaływanie społeczności więźniów znacznie utrudnia przeprowadzanie resocjalizacji" (Pierzchała 2016, s. 22).

Najczęściej współczesne koncepcje socjalizacyjne osób niedostosowanych społecznie oparte są na grupie społecznej (rodzinie, społeczności lokalnej, rówieśnikach) (Pierzchała 2013, s. 398) i w grupie tej znajdują argumenty przemawiające za celowością ludzkiego istnienia. Osoba - w tej koncepcji - traktowana jest jako część/element systemu społecznego. W nowym stanowisku do resocjalizacji (Konopczyński 2010, s. 43 i in.; Bałandynowicz 2011, s. 105 i in.) grupa przestaje być wyłącznym wyznacznikiem sensowności ludzkiego życia. To sam człowiek staje się twórcą i wykonawcą „celu własnego życia” i nie może mu go narzucić nikt, poza sobą samym. Człowiek „[...] nie może odnaleźć się w pełni inaczej jak tylko poprzez bezinteresowny dar z siebie samego" - zawarte jest w Konstytucji duszpasterskiej Soboru Watykańskiego II (Sobór Watykański II 1965, KDK 24). Aby człowiek, któremu niestety często towarzyszy bolesne doświadczenie egzystencjalnego zagubienia w świecie, całkowicie nie zatracił siebie, potrzeba przy- 
pominania i zapraszania do tego, co może rzeczywiście wynieść go na wyżyny człowieczeństwa. Resocjalizacja nie tylko powinna doprowadzać do ukształtowania/ zbudowania nowej tożsamości społecznej wychowanka, ale też szczególnie powinna polegać na wykształceniu osoby w pełni „normalnej”, autentycznej, pewnej swojej wolności i związanej z nią odpowiedzialności za siebie samego, innych oraz za świat, w którym funkcjonuje, w którym żyje.

Współcześnie niedopuszczalne jest najprostsze przeciwstawianie wartości społecznych - wartościom jednostki. Anetta Jaworska jest zdania, iż „[...] pozornie może się wydawać, że to, co dobre dla jednostki, nie zawsze jest dobre dla społeczeństwa, i odwrotnie - to, co pożądane przez społeczeństwo, nie zawsze służy pojedynczemu człowiekowi. W rzeczywistości, na poziomie gruntownych rozważań aksjologicznych, jedynie człowiek dostrzegający wartość samego siebie, własnego potencjału rozwojowego i własnego życia jest w stanie cenić wartość otaczających go środowisk naturalnych: społecznego i przyrodniczego. To, co autentycznie służy człowiekowi i prowadzi do zaspokojenia jego immanentnych potrzeb (nie zachcianek!), służy jednocześnie dobru otaczającego świata. Równocześnie społeczeństwo, dla którego najwyższą wartością jest dobro każdego człowieka, a nie jedynie restrykcje mające zmusić go do uległości, ma szanse na budowanie trwałego i opartego na sprawiedliwości ładu społecznego" (Jaworska 2012, s. 28 i 29).

\section{ZADANIA WYCHOWANIA RESOCJALIZUJĄCEGO}

Zadania wychowania resocjalizującego wyznacza ideał wychowawczy, a to nic innego jak nakreślone cele wychowania, które opisują wzór osobowości do jakiego dążyć powinno wychowanie resocjalizujące:

1. Likwidacja przyczyn - wyeliminowanie czynników, które wywołują albo powodują zaburzone stany osobowości:

a) eliminowanie impulsywności - poprzez prowadzenie określonych ćwiczeń procesów nerwowych, prowadzących do pełnej homeostazy, czyli równowagi między procesami pobudzania i hamowania (np. poprzez usuwanie sytuacji, które są zbyt stresujące, poprzez uczenie wychowanków systematyczności, dbanie o atrakcyjność zajęć),

b) stwarzanie warunków do czynności psychoruchowych,

c) kształtowanie refleksyjności (refleksja jest filtrem emocji i rozwija zdolność do działań problemowych, sprzyja analizowaniu), 
d) wzmacnianie siły woli, oznaczającej zdolność do podejmowania rozsądnych decyzji, zdolność do realizowania powziętego postanowienia, pomimo wewnętrznych i zewnętrznych oporów. Silna wola zależy od:

- kształtowania się światopoglądu o rozwoju uczuć moralnych,

- umiejętność podejmowania decyzji,

- realnej oceny zamiarów i własnych możliwości

- umiejętności jednostki oceniania własnych działań,

- stałego treningu w przezwyciężaniu wewnętrznych oporów;

2. Eliminowanie przyczyn nieadekwatności, którymi mogą być zaburzenia emocjonalne, powstałe podczas doświadczeń życiowych.

a) ustabilizowanie sytuacji rodzinnej,

b) usuwanie sytuacji trudnych, których rozwiązanie przekracza aktualne możliwości nieletniego.

\section{WYCHOWANIE RESOCJALIZACYJNE A ETYKA}

Wydaje się, iż $\mathrm{w}$ centrum ponadczasowego i ponadkulturowego podejścia do resocjalizacji powinny znajdować w głównej mierze kwestie etyczne (zagadnienia moralnego dobra i zła) (Lekka-Kowalik 2016, s. 347-353). Bezspornym jest fakt, że to, co etyczne, nigdy nie jest/będzie relatywne (zależne od czegoś, np. od przyjętego punktu widzenia), ale zawsze winno być umocowane w niedopuszczaniu do zbędnego ludzkiego cierpienia (Szkudlarek, Śliwerski 2010). Aksjologia resocjalizacji usytuowana jest więc na styku dwóch paradygmatów: humanistycznego i funkcjonalnego, nie dając pierwszeństwa ani wartościom społecznym, kulturowym, czy też historycznym, ani tym, które wybierają wolność, godność i podmiotowość wszystkich ludzi, każdego człowieka, jako niepowtarzalnej jednostki - mającej prawo do szczęścia (Jaworska 2012, s. 29). W tym względzie najlepsza jest równowaga. „Stąd też w ramach swoich rozważań pedagogiczno-resocjalizacyjnych, w zgodzie z wymową Magisterium Kościoła, sformułowałem koncepcję (współbrzmiącą z szeroko pojmowanym nurtem humanistyczno-egzystencjalnym, m.in. z psychologią humanistyczną i pozytywną, a także z wychowaniem aksjologicznym ukierunkowanym na osobowościowy potencjał człowieka), którą nazwałem personalistyczną aksjologią resocjalizacji”" (Pierzchała 2016, s. 178). 


\section{PODSUMOWANIE}

Wychowanie resocjalizacyjne jest procesem bezprecedensowym w społeczeństwie, ponieważ nie tylko pozwala ona na utrzymanie swoistej równowagi pomiędzy osobami dostosowanymi a nieprzystosowanymi społecznie, ale także stoi na przeszkodzie w zupełnej destrukcji człowieka, jaką potrafi wywołać długotrwały pobyt w instytucji penitencjarnej. Proces resocjalizacji stanowi niewątpliwą nadzieję, że system wymiaru sprawiedliwości nie jest wyłącznie bezdusznym narzędziem, skierowanym w społecznie nieprzystosowane jednostki, ale że finalnie potrafi kształtować w tych osobach odpowiednią - społecznie pożądaną - skalę wartości i norm.

„Zadaniem osoby prowadzącej swojego wychowanka będzie więc także a może przede wszystkim - odkrycie przed nim, ukazanie mu sensu jego życia i dotychczasowych doświadczeń, jak również sensu świata wyższych wartości, których recepcja, przeżycie i zaangażowanie się w nie są materialnymi nośnikami egzystencjalnego sensu. Odczuwanie sensu względem czegoś jest też niejako atrybutem bycia człowiekiem w jego osobowym wymiarze” (Pierzchała 2016, s. 111).

„Proces resocjalizacji znajduje uzasadnienie poprzez fakt, że u przestępców występuje odmienny schemat postrzegania rzeczywistości, niż ten ukształtowany potocznie. Zatem resocjalizacja to przywracanie powszechnego (potocznego) rozumienia dobra i zła oraz zmiana nastawień wobec innych, powszechnie akceptowanych wartości" (Świda-Zięba 1989, s. 5).

Na zakończenie artykułu przytoczę słowa klasyka polskiej resocjalizacji Stanisława Jedlewskiego: „Sam system, choć najlepszy, jeszcze nie wychowuje, dobry system może jedynie stworzyć odpowiednie ramy, możliwości, sytuacje sprzyjające, wychowują zaś wychowawcy, ich postawy pedagogiczne" (Szczepaniak 2005, s. 300).

\section{LITERATURA}

Bałandynowicz A., 2011, Probacja. Resocjalizacja z udziałem społeczeństwa, Wyd. II. Warszawa, Wydawnictwo Lex a Wolters Kluwer Business.

Bałandynowicz A., 2015, Probacja sprawiedliwość karząca. Warszawa, Wydawnictwo Wolters Kluwer.

Czapów C., 1978, Wychowanie resocjalizujące. Elementy metodyki i diagnostyki. Warszawa, Wydawnictwo PWN.

Jaworska A., 2012, Leksykon resocjalizacji. Kraków, Oficyna Wydawnicza „Impuls”. Konopczyński M., 2010, Metody twórczej resocjalizacji. Warszawa, Wydawnictwo

Naukowe PWN - Pedagogium. 
Lekka-Kowalik A., 2016, Etyka. W: K. Chałas, A. Maj (red.), Encyklopedia aksjologii pedagogicznej. Radom, Polskie Wydawnictwo Encyklopedyczne, s. 347-353.

Maj A., 2016, Aksjologia i Aksjologia pedagogiczna. W: K. Chałas, A. Maj (red.), Encyklopedia aksjologii pedagogicznej. Radom, Polskie Wydawnictwo Encyklopedyczne, s. $82-87$ i 87-91.

Nowak M., Magier P., Szewczak I. (red.), 2010, Antropologiczna pedagogika ogólna. Lublin, Wydawnictwo Archidiecezji Lubelskiej „GAUDIUM”.

Okoń W., 1998, Nowy słownik pedagogiczny. Warszawa, Wydawnictwo Akademickie „Żak”.

Ostrowska U., 2006, Aksjologiczne podstawy wychowania. W: Śliwerski B. (red.), Pedagogika. Podstawy nauk o wychowaniu, t. 1. Gdańsk, Gdańskie Wydawnictwo Psychologiczne.

Pierzchała K., 2013, Kapelan więzienny w procesie resocjalizacji penitencjarnej. Toruń, Wydawnictwo Adam Marszałek.

Pierzchała K., 2016, Destygmatyzacja przestępców w świetle Magisterium Kościoła oraz poglądów na resocjalizację. Kraków, Oficyna Wydawnicza „Impuls”.

Pierzchała K., 2017. Wina - prawo - kara. Prawne i psychopedagogiczne aspekty resocjalizacji penitencjarnej. „Probacja”, 2.

Pytka L., 2005, Pedagogika resocjalizacyjna. Wybrane zagadnienia teoretyczne, diagnostyczne i metodyczne, Wydanie VI. Warszawa, Wydawnictwo Akademii Pedagogiki Specjalnej.

Sobór Watykański II, 1965, Konstytucja duszpasterska o Kościele w świecie współczesnym „Gaudium et spes”. Rzym.

Suchodolski B., 1967, Świat człowieka a wychowanie. Warszawa, Wydawnictwo „Książka i Wiedza”.

Szczepaniak P., 2005, Kara pozbawienia wolności a wychowanie. „Przegląd Więziennictwa Polskiego", 49.

Szkudlarek T., Śliwerski B., 2010, Wyzwania pedagogiki krytycznej i antypedagogiki, Wydanie V. Kraków, Oficyna Wydawnicza „Impuls”.

Świda-Zięba H., 1989, Tworzenie więzi społecznej w procesie resocjalizacji. W: Wspólnota religijna a duszpasterstwo w zakładach penitencjarnych. „Materiały seminaryjne”, 1.

Tischner J., 1982 (2011), Myślenie według wartości. Kraków, Społeczny Instytut Wydawniczy „Znak”.

Tischner J., 1984, Etyka wartości i nadziei. W: von D. Hildebrand, J.A. Kłoczowski, J. Paściak, J. Tischner (red.), Wobec wartości. Poznań, Wydawnictwo „W drodze”. Tischner J., 2010, Myśli wyszukane. Kraków, Społeczny Instytut Wydawniczy „Znak”. Walczak P., 2007, Wychowanie jako spotkanie. Józefa Tischnera filozofia człowieka jako źródło inspiracji pedagogicznych. Kraków, Oficyna Wydawnicza „Impuls”. 


\title{
THE AXIOLOGICAL CONTEXTS OF RESOCIALIZATION EDUCATION
}

\begin{abstract}
The purpose of the article is to present the basic axiological issues of resocialization contexts. The method used is: material development and critical edition. Rehabilitation is an unprecedented process in society, because it not only allows for maintaining a specific balance between adjusted and socially maladjusted persons, but also hinders the total destruction of a human being that can cause a long stay in a penitentiary institution. The process of resocialisation is undoubtedly a hope that the system of justice is not only a soulless tool directed at socially maladjusted individuals, but it will also shape appropriate scales of values and norms in these people.
\end{abstract}

Keywords: axiology, social maladjustment, resocialization, criminal, foster child, resocialization education 